\title{
DISTRIBUTION STRATEGIEY OF SOME CROPS IN EGYPT GOVERNORATES BY USING WATER FOOTPRINT ANALYSIS
}

\author{
M. H. Ramadan (1), M. M. Ibrahim ${ }^{(2)}$, Khalil, A. A. ${ }^{(3)}$
}

\begin{abstract}
Egypt suffers from non-efficient irrigation water use and bad allocation of cropping areas among its governorates, in addition to its shortage water problems. Water footprint refers to the volume of water used to produce the crop, measured over the full planting time. Crops cultivated regardless of its water footprint which differ according to each governorate. Water footprint was conducted to enhance water use efficiency and recover water scarcity problems in Egypt. So in this study, total water footprint over the period from 2008 to 2012 was quantified for each governorate in Egypt for Rice, Maize and wheat crops from hydrological perspective. From results, it is recommended to plant Rice in Dakahlia, Kafr El-Sheikh and Damietta due to the lowest water footprint (1101.8, 1214.9 and 1280.3 $\mathrm{m}^{3} /$ ton, respectively) and highest Rice yield. However, it is more profitable to plant Maize in Dakahlia and Noubaria as they have the lowest values of water footprint (1227.4 and $1399.5 \mathrm{~m}^{3} /$ ton, respectively) and highest yield. With respect to Wheat crop, it was found that, the best governorates to be planted were Behera, Dakahlia, Damietta and Kafer El-shiekh where the values of water footprint were 1323.1, 1323.3, 1378.1 and 1387.1 $\mathrm{m}^{3} /$ ton, respectively as the yield was high in the previous governorates.
\end{abstract}

Key words: water footprint, green water footprint, blue water footprint, total water footprint, Rice, Maize, Wheat, Egypt.

\section{INTRODUCTION}

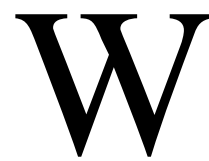
ater is one of the most important natural resources on our planet and a fundamental element of life whose preciousness requires diligent management. The recent increase in the use of freshwater as a result of human activities has lead to serious water scarcity in many regions (Gerbens-Leenes and Hoekstra, 2008).

\footnotetext{
${ }^{1}$ Prof. and ${ }^{2}$ Assistant Prof. of Agric. Eng. Dept., Faculty of Agric, Al-Mansoura Univ.

${ }^{3}$ Engineer in, Agric. Eng. Res. Institute (AERI) - El-Dokki, Cairo.
} 
A recent McKinsey report1 predicts that by 2030, global water requirements will have grown from 4,500 billion $\mathrm{m}^{3}$ today to 6,900 billion $\mathrm{m}^{3}$. These worrying trends make managing and conserving water resources so vitally important (Felix, 2012). Irrigation water management is managing soil moisture so that an optimum quantity of irrigation water is applied at appropriate times. Good water management can both increase crop production and reduce costs

(USDA and MSU, 1990). By linking a large range of sectors and issues, virtual water and water footprint analyses provide an appropriate framework to find potential solutions and contribute to a better management of water resources (Aldaya and Llamas, 2008). More over it is a must to manipulate water use strategy. The water footprint is a multidimensional indicator, showing water consumption volumes by source and polluted volumes by type of pollution; all components of a total water footprint are specified geographically and temporally (Hoekstra $\boldsymbol{e t}$ al., 2011). Detailed national water footprint studies have been conducted for European countries, (Van Oel et al., 2009) and countries outside Europe, (Bulsink et al., 2010); (Liu and Savenije, 2008); and (Verma et al., 2009). To reduce the pressure putting on fresh water resources, assessment of blue, green, and grey water footprint would be conducted. A spatially and temporally explicit water footprint analysis is also required by the variability of water resources in space and time (Mekonnen, 2011). So the objectives of this study was to estimate the total water footprint for Rice, Maize and Wheat in Egypt governorates over the period 2008 to 2012. It helps decision maker promoting the most suitable governorate to plant each crop and adjust crops planted areas to decrease irrigation water consumption and save water

\section{METHODOLOGY}

The present study estimates the total water footprint of Rice, Maize and Wheat in Egypt governorates through the period from 2008-2012 and considers the green, blue and grey water components for these crops. This was done according to the crop data available for each governorate.

The water footprint calculated using the methodology developed by Hoekstra and Hung (2002; 2005) and Chapagain and Hoekstra (2003; 2004). The virtual water content of a product is the volume of freshwater 
used to produce it, which depends on the water used in the various steps of the production chain. The virtual water content of primary crops $\left(\mathrm{m}^{3} /\right.$ ton) (i.e. crops in the form in which they come directly from the land without having undergone any processing) has been calculated at a provincial level as the ratio of the volume of water used during the entire period of crop growth (crop water use, $\mathrm{m}^{3} /$ year) to the corresponding crop yield (ton/ha) in the production region. The crop water requirement of a certain crop under particular climate was estimated using the CROPWAT model (Allen et al., 1998; FAO, 2003) using climate data at the governorates.

Crop water requirements (CWR) for crop were divided to two components: the green crop water requirements $\left(\mathrm{CWR}_{\text {green }}\right)$ (amount of water crop takes it from rainfall) and the blue crop water requirements $\mathrm{CWR}_{\text {blue }}$ (amount of water embedded to the system of irrigation to cover crop requirements). The green and blue components in crop water use (CWR, $\mathrm{m}^{3} / \mathrm{ha}$ ) were calculated by accumulation of daily evapotranspiration (ET, $\mathrm{mm} /$ day) over the complete growing period (Hoekstra et al., 2011) as indicated in equations (1) and (2) as follows:

$$
\begin{aligned}
& \mathrm{CWR}_{\text {green }}\left(\mathrm{m}^{3} / \mathrm{ha}\right)= \\
& 10 \sum_{\mathrm{d}=1}^{1 \mathrm{gp}} \mathrm{ET}_{\text {green }} \\
& \text { CWR }_{\text {blue }}\left(\mathrm{m}^{3} / \mathrm{ha}\right) \\
& =10 \sum_{\mathrm{d}=1}^{1 \mathrm{gp}} \mathrm{ET}_{\text {blue }} \ldots \ldots \ldots \ldots \ldots \ldots \ldots \ldots \ldots
\end{aligned}
$$

CWR is the crop water requirements (either green or blue) in $\mathrm{m}^{3} / \mathrm{ha}$. ET is the daily evapotranspiration (either green or blue) in $\mathrm{mm}$.

Green water footprint $\left(\mathrm{WF}_{\text {green }}\right)$ was the consumptive use of rain water embedded in the soil. Blue water footprint $\left(\mathrm{WF}_{\text {blue }}\right)$ was the consumptive use of water withdrawn from groundwater or surface water. Grey water footprint $\left(\mathrm{WF}_{\text {grey }}\right)$ refers to the pollution of water associates with the production of crop along the growing period. The fraction of applied chemicals that enter the water system can be estimated by using simple or more advanced models by dividing the pollutant load by the difference between the maximum acceptable concentration for that pollutant of water 
and its natural concentration in the receiving water body. The last value is divided by the crop yield (Y) to calculate the grey water footprint. So total water footprint $\left(\mathrm{WF}_{\mathrm{Tot}}\right)$ calculated as follows:

$$
\begin{aligned}
\mathrm{WF}_{\text {Tot }}\left(\mathrm{m}^{3} / \text { ton }\right) & =\frac{\mathrm{CWR}_{\text {green }}}{\mathrm{Y}}+\frac{\mathrm{CWR}_{\text {blue }}}{\mathrm{Y}} \\
& +\left[\frac{\propto * \text { Appl }}{\mathrm{c}_{\text {max }}-\mathrm{c}_{\text {nat }}}\right] / \mathrm{Y} \ldots \ldots \ldots
\end{aligned}
$$

Appl is the application rate of chemicals to the field per hectare in $(\mathrm{kg} / \mathrm{ha}) . \mathrm{c}_{\max }$ is the maximum acceptable concentration in $\left(\mathrm{kg} / \mathrm{m}^{3}\right) . \mathrm{c}_{\text {nat }}$ is the natural concentration for Nitrogen in $\left(\mathrm{kg} / \mathrm{m}^{3}\right) . \alpha$ is the leaching-run-off fraction; and $\mathrm{Y} \quad$ is the yield in (ton/ha).

\section{RESULTS AND DISCUSSION}

The water footprint flow analyses for Rice, Maize and Wheat crops are evaluated over the period (2008-2012) for each governorate to achieve the aims of this study.

\section{Rice crop}

\section{1- Governorates cropping area}

According to agriculture directorates statistics, Table 1 illustrates the average planted area for Rice over the period (2008-2012) for Egypt governorates. It is clear that, the cultivated areas in Dakahlia and Kafer_Elsheikh were the highest among other governorates. However the lowest cultivated Rice areas were in Suez, Cairo and Assuit.

\section{2- Crop water requirements}

CWR includes two components: effective rainfall (green water) and irrigation water (blue water). CWR refers to the water needed for evapotranspiration under ideal growth conditions, measured from planting to harvest. As shown in Figure 1, over the period from 2008 to 2012, New Valley had the largest average of CWR $\left(15840.2 \mathrm{~m}^{3} / \mathrm{ha}\right)$. On the other hand, Ismailia and Port Said had the lowest CWR (8608.8, 8608.4 m3/ha respectively). This result is due to climatic condition. 
Table 1: The total planted area (ha) for Rice in (2008-2012) for Egypt governorates

\begin{tabular}{|l|c|c|c|c|c|c|}
\hline \multirow{2}{*}{ Governorates } & \multicolumn{7}{|c|}{ Area (ha) } \\
\cline { 2 - 7 } & $\mathbf{2 0 0 8}$ & $\mathbf{2 0 0 9}$ & $\mathbf{2 0 1 0}$ & $\mathbf{2 0 1 1}$ & $\mathbf{2 0 1 2}$ & Average \\
\hline Alexandria & 1885 & 857 & 71 & 1068 & 859 & 948 \\
\hline Behera & 97830 & 84098 & 65028 & 88570 & 83951 & 83895.4 \\
\hline Gharbia & 74972 & 53261 & 44054 & 51787 & 61756 & 57166 \\
\hline kafer_El-sheikh & 150484 & 136341 & 116102 & 124535 & 121851 & 129862.6 \\
\hline Dakahlia & 205567 & 151071 & 120688 & 177077 & 190969 & 169074.4 \\
\hline Damietta & 31077 & 27184 & 23709 & 29060 & 28107 & 27827.4 \\
\hline Sharkia & 142120 & 107659 & 78496 & 99308 & 110382 & 107593 \\
\hline Ismailia & 1983 & 1661 & 1357 & 2287 & 2582 & 1974 \\
\hline port said & 8995 & 8475 & 6533 & 9412 & 8394 & 8361.8 \\
\hline Suez & 0 & 18 & 0 & 0 & 0 & 3.6 \\
\hline Menoufia & 0 & 0 & 0 & 0 & 549 & 109.8 \\
\hline Qalyoubia & 11391 & 4175 & 2218 & 6958 & 6484 & 6245.2 \\
\hline Cairo & 14 & 4 & 3 & 0 & 1 & 4.4 \\
\hline Beni suef & 627 & 198 & 42 & 120 & 288 & 255 \\
\hline Fayoum & 12706 & 0 & 0 & 0 & 313 & 2603.8 \\
\hline Assuit & 81.5 & 5 & 0 & 0 & 0 & 17.3 \\
\hline New valley & 2829 & 6 & 825 & 1543 & 1682 & 1377 \\
\hline Noubaria & 732 & 55 & 53 & 109 & 117 & 213.2 \\
\hline
\end{tabular}

\section{3- Green, blue, and grey water footprint for Rice}

Mostly there is a rare rain in Egypt. Therefore, $\mathrm{WF}_{\text {blue }}$ for Rice is higher than the $\mathrm{WF}_{\text {green }}$ and $\mathrm{WF}_{\text {grey }}$ (Figure 2). The $\mathrm{WF}_{\text {blue }}$ for Rice is 1281 $\mathrm{m}^{3} /$ ton through the period 2008-2012. On the other hand, the $\mathrm{WF}_{\text {grey }}$ for Rice is approximately $7.11 \mathrm{~m}^{3} /$ ton over the period 2008-2012. In addition the $\mathrm{WF}_{\text {grey }}$ for Rice is $309 \mathrm{~m}^{3} /$ ton, due to the addition of Nitrogen during the growing season.

Over the period 2008-2012, as shown in Figure 2 Dakahlia has the lowest $\mathrm{WF}_{\text {blue }}$ for Rice $\left(848.7 \mathrm{~m}^{3} /\right.$ ton in average) and it has the lowest $\mathrm{WF}_{\text {grey }}$ $\left(242.3 \mathrm{~m}^{3} /\right.$ ton in average) due to the highest Rice yield . On the other hand, the highest $\mathrm{WF}_{\text {blue }}$ for Rice in 2008 to 2012 in New Valley was $1977.2 \mathrm{~m}^{3} /$ ton in average and its average $\mathrm{WF}_{\text {grey }}$ was $314.5 \mathrm{~m}^{3} / \mathrm{ha}$. In 2008 Noubaria had the highest $\mathrm{WF}_{\mathrm{blue}}$ for Rice. These results could be due to the differences in soil type and climate conditions although the lowest Rice yield in Noubaria causes the highest $\mathrm{WF}_{\text {grey }}$ Because the green water footprint was dependant on rain in each governorate. 


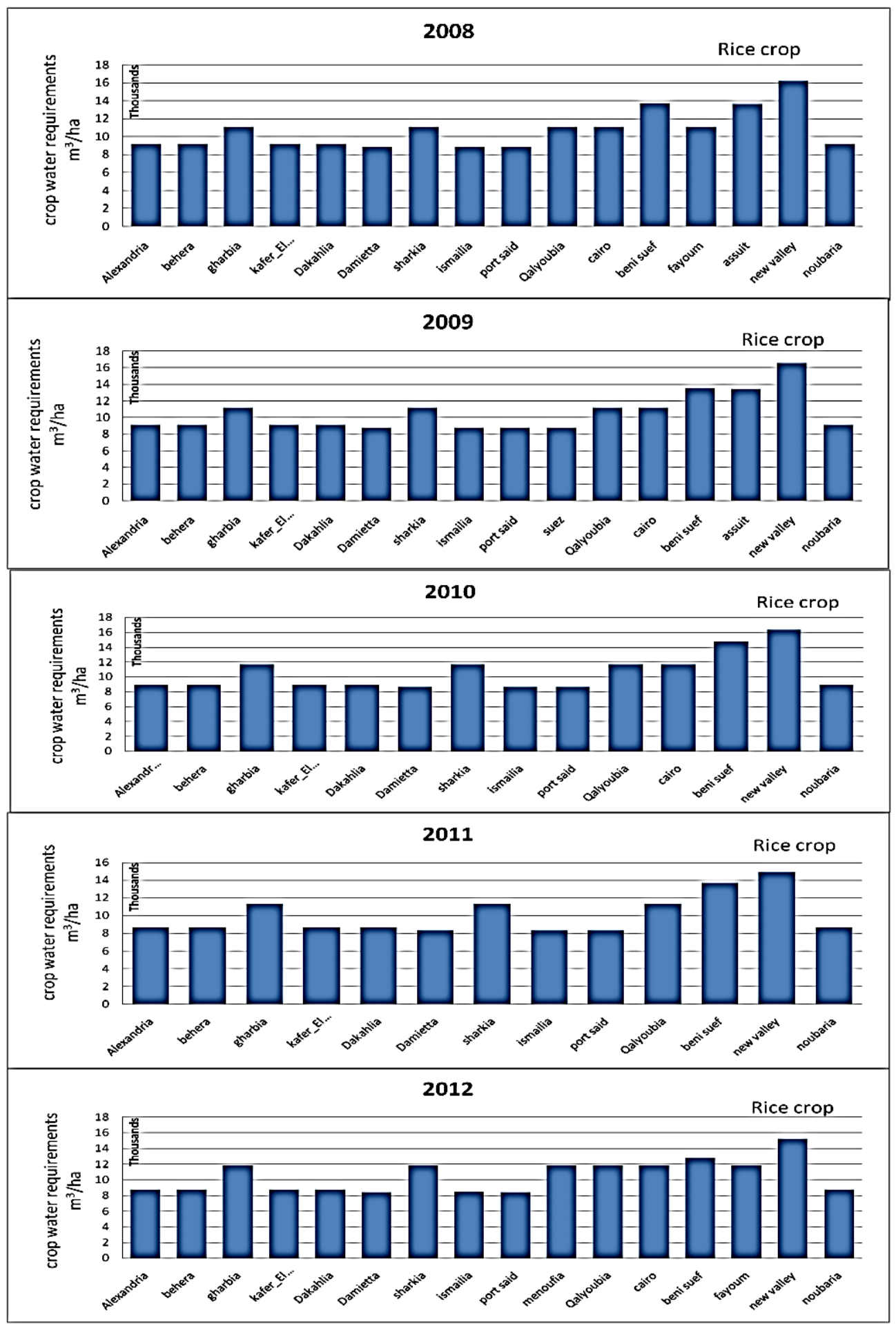

Figure 1: Crop water requirements for Rice in Egypt governorates from 2008 to 2012. 


\section{4- Total water footprint for Rice}

The water footprint analysis established the amount of water required by specific crops and it differs according to crop type, yield and climate. Water footprint also depends on the amount of nitrogen applied to the soil during growing season. Although increasing the amount of nitrogen applied to the soil causes increasing in total water footprint, decreasing the amount of nitrogen applied to the soil may cause decreasing in Rice yield. So the amount of nitrogen applied to the soil should be controlled to benefit crop and not waste water. Figure 3 illustrate the results for the period from 2008 to 2012 and by estimating the averages of this period, the results were as follows; Noubaria had the largest $\mathrm{WF}_{\mathrm{Tot}}\left(2200 \mathrm{~m}^{3} /\right.$ ton $)$ and New Vally had $2292.5 \mathrm{~m}^{3} /$ ton. This result is due to hot climate and lower Rice yield in this governorates. On the other hand, Dakahlia had the lowest $\mathrm{WF}_{\text {Tot }}$ $\left(1101.8 \mathrm{~m}^{3} /\right.$ ton). Followed by Kafr El-Sheikh and Damietta had low values (1214.9 and $1280.3 \mathrm{~m}^{3} /$ ton respectively). These results are due to the huge planted areas of Rice and their high yield.

\section{Maize crop}

\section{1- Cropping area}

Table 2 shows the total planted area for Maize over period 2008 to 2012. From the five years average, it is clear that Sharkia and Menia had the largest Maize planted areas however, Sharkia had the largest planted area in 2010. Cairo and North Sinai had the lowest planted area through the study period.

\section{2- Crop water requirements for Maize}

From the results show in Figure 4, New Valley and Aswan had the largest CWR for Maize which are 11707.8 and $11860.4 \mathrm{~m}^{3} / \mathrm{ha}$ while, North Sinai had the lowest values $\left(606.6 \mathrm{~m}^{3} / \mathrm{ha}\right)$. Differences among governorates climatic conditions explain these results.

\section{3- The green, blue, and grey water footprint for Maize}

The $\mathrm{WF}_{\text {blue }}$ for Maize was $1420.5 \mathrm{~m}^{3} /$ ton during the period 2008 to 2012, While the $\mathrm{WF}_{\text {green }}$ for Maize was $22.9 \mathrm{~m}^{3} /$ ton. This is due to planting Maize in summer season where there is littleness rain in Egypt. In addition, the $\mathrm{WF}_{\text {grey }}$ for Maize was $900.37 \mathrm{~m}^{3} /$ ton due to applying a huge Nitrogen during growing season. As illustrated in Figure 5, Dakahlia had the lowest $\mathrm{WF}_{\text {blue }}\left(678.6,671.9,666.24,685.8\right.$ and $626.5 \mathrm{~m}^{3} /$ ton through 2008 to 2012, respectively). 


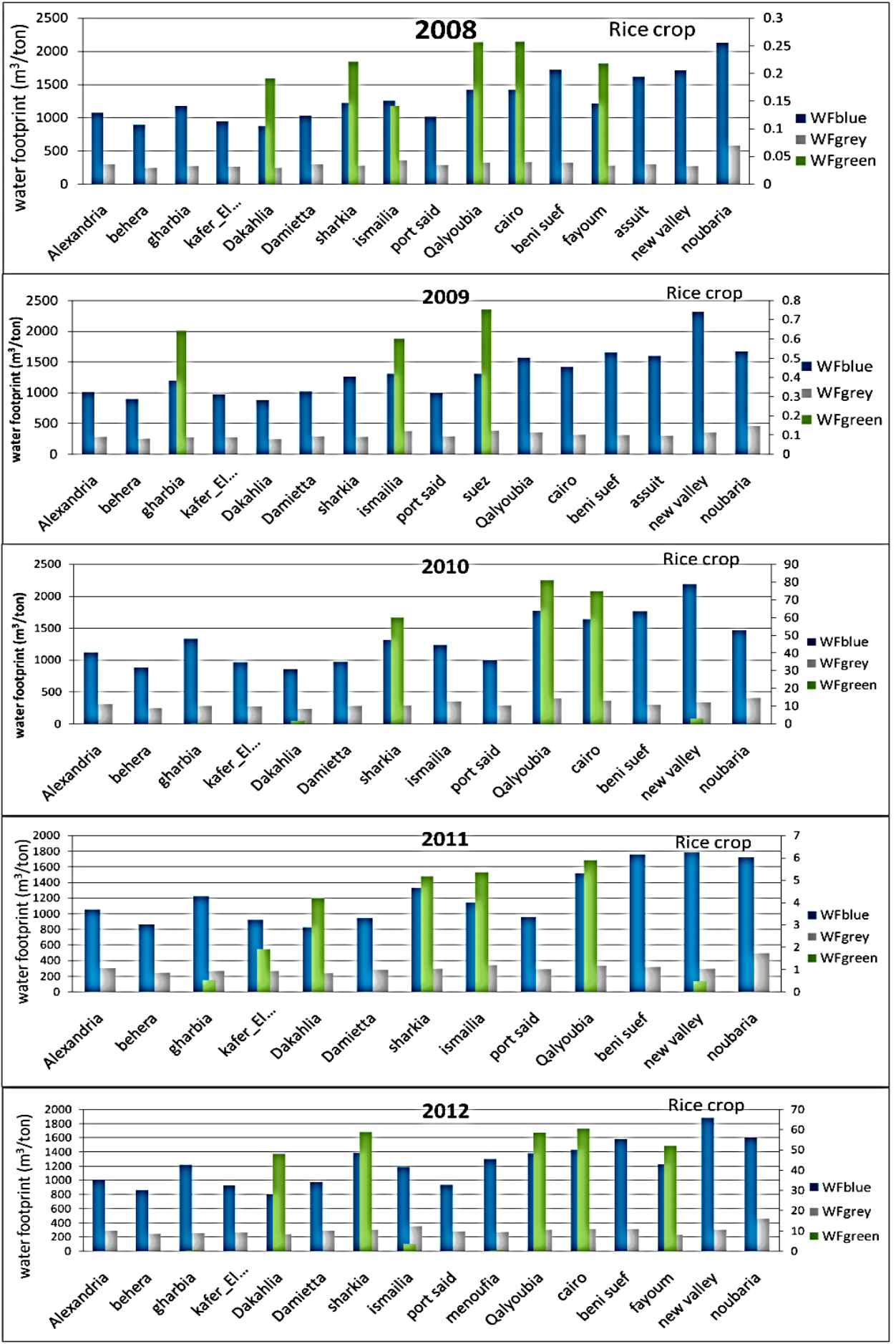

Figure 2: Green, blue and grey water footprint for Rice in Egypt governorates from 2008 to 2012. 


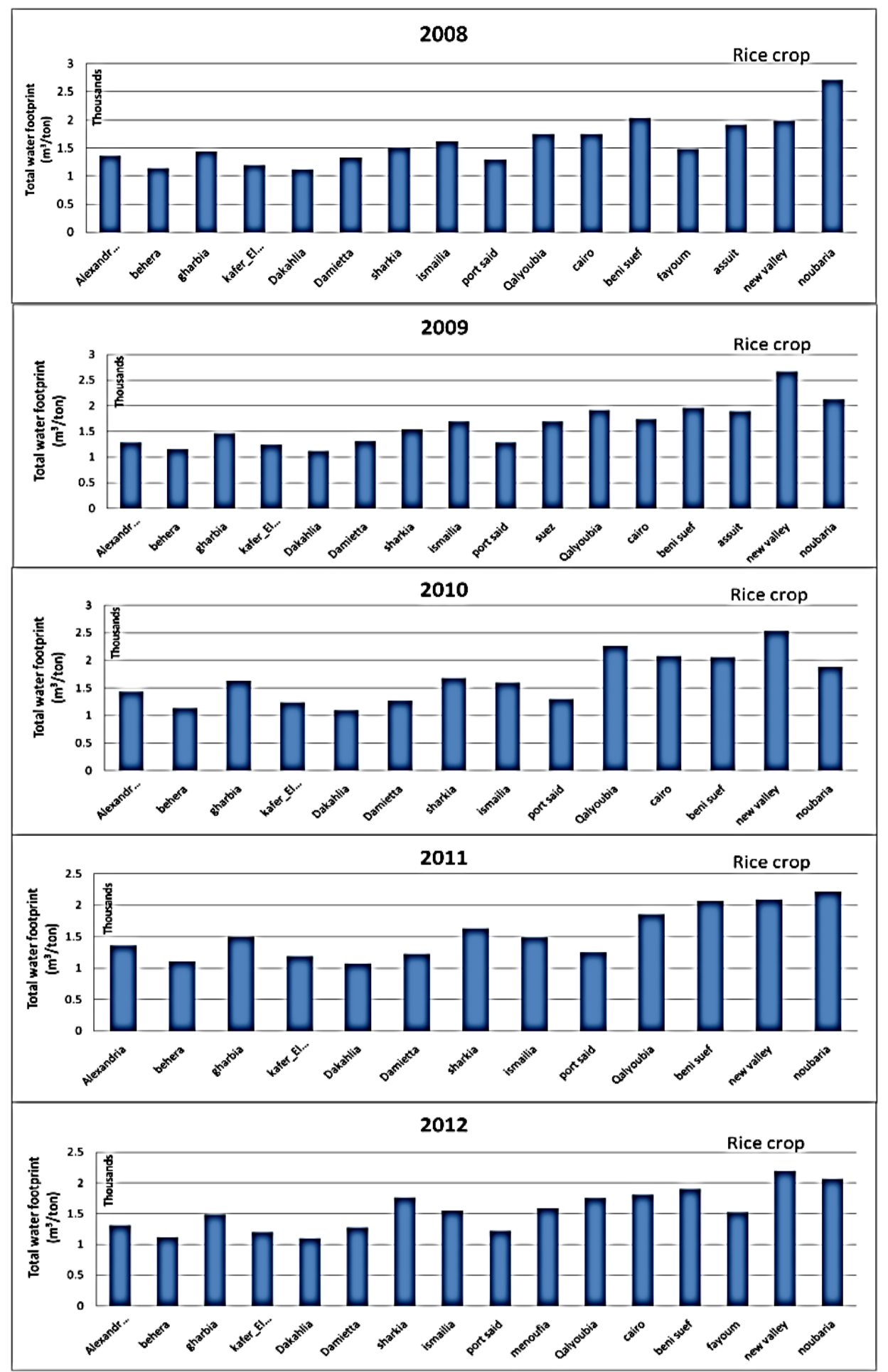

Figure 3: Total water footprint for Rice in Egypt governorates from 2008 to 2012. 
Table 2: The planted Maize area (ha) for Egypt governorates from 2008 to 2012

\begin{tabular}{|l|c|c|c|c|c|c|}
\hline \multirow{2}{*}{ Governorates } & \multicolumn{6}{|c|}{ Area (ha) } \\
\cline { 2 - 7 } & $\mathbf{2 0 0 8}$ & $\mathbf{2 0 0 9}$ & $\mathbf{2 0 1 0}$ & $\mathbf{2 0 1 1}$ & $\mathbf{2 0 1 2}$ & Average \\
\hline Alexandria & 14453 & 14175 & 12841 & 13349 & 14957 & 13955 \\
\hline Behera & 76021 & 88370 & 73164 & 63986 & 94145 & 79137.2 \\
\hline Gharbia & 28422 & 26592 & 20501 & 18903 & 26940 & 24271.6 \\
\hline kafer_El sheikh & 22693 & 22546 & 25662 & 23192 & 33560 & 25530.6 \\
\hline Dakahlia & 24233 & 37657 & 52705 & 22906 & 24305 & 32361.2 \\
\hline Damietta & 897 & 1548 & 3648 & 741 & 764 & 1519.6 \\
\hline Sharkia & 84878 & 98522 & 131513 & 101177 & 106029 & 104423.8 \\
\hline Ismailia & 16055 & 15674 & 14168 & 13583 & 15246 & 14945.2 \\
\hline Port said & 1019 & 5953 & 3749 & 3040 & 4736 & 3699.4 \\
\hline Suez & 1351 & 1497 & 1358 & 1090 & 1182 & 1295.6 \\
\hline Menoufia & 68620 & 38521 & 67295 & 81705 & 89876 & 69203.4 \\
\hline Qalyoubia & 31705 & 40184 & 37069 & 24997 & 30720 & 32935 \\
\hline Cairo & 55 & 11 & 8 & 96 & 50 & 44 \\
\hline Giza & 11725 & 693 & 462 & 20746 & 26990 & 12123.2 \\
\hline Beni Suef & 71839 & 63506 & 58021 & 56472 & 75044 & 64976.4 \\
\hline Fayoum & 27323 & 46040 & 32564 & 26105 & 41323 & 34671 \\
\hline Menia & 126653 & 128236 & 108867 & 105189 & 123006 & 118390.2 \\
\hline Assuit & 55162 & 57675 & 57145 & 51412 & 66890 & 57656.8 \\
\hline Suhag & 54727 & 55723 & 57411 & 53812 & 58856 & 56105.8 \\
\hline Qena & 22994 & 21488 & 16685 & 16166 & 21708 & 19808.2 \\
\hline Luxor & 6018 & 5619 & 7005 & 6800 & 8188 & 6726 \\
\hline Aswan & 5793 & 5267 & 3856 & 4072 & 3898 & 4577.2 \\
\hline New Valley & 667 & 2412 & 152 & 83 & 3085 & 1279.8 \\
\hline Matruh & 2373 & 4553 & 1302 & 1257 & 546 & 2006.2 \\
\hline North Sinai & 161 & 131 & 67 & 51 & 73 & 96.6 \\
\hline Noubaria & 25501 & 26168 & 24517 & 27653 & 33836 & 27535 \\
\hline
\end{tabular}

The average values through the study period for Dakahlia, Noubaria and Damietta were $665.8,770.2$ and $774.2 \mathrm{~m}^{3} /$ ton respectively. On the contrary, the highest $\mathrm{WF}_{\text {blue }}$ for Maize for the study period was in North Sinai, New Valley and Aswan (376, 2355.4 and $2173.2 \mathrm{~m}^{3} /$ ton, respectively). 


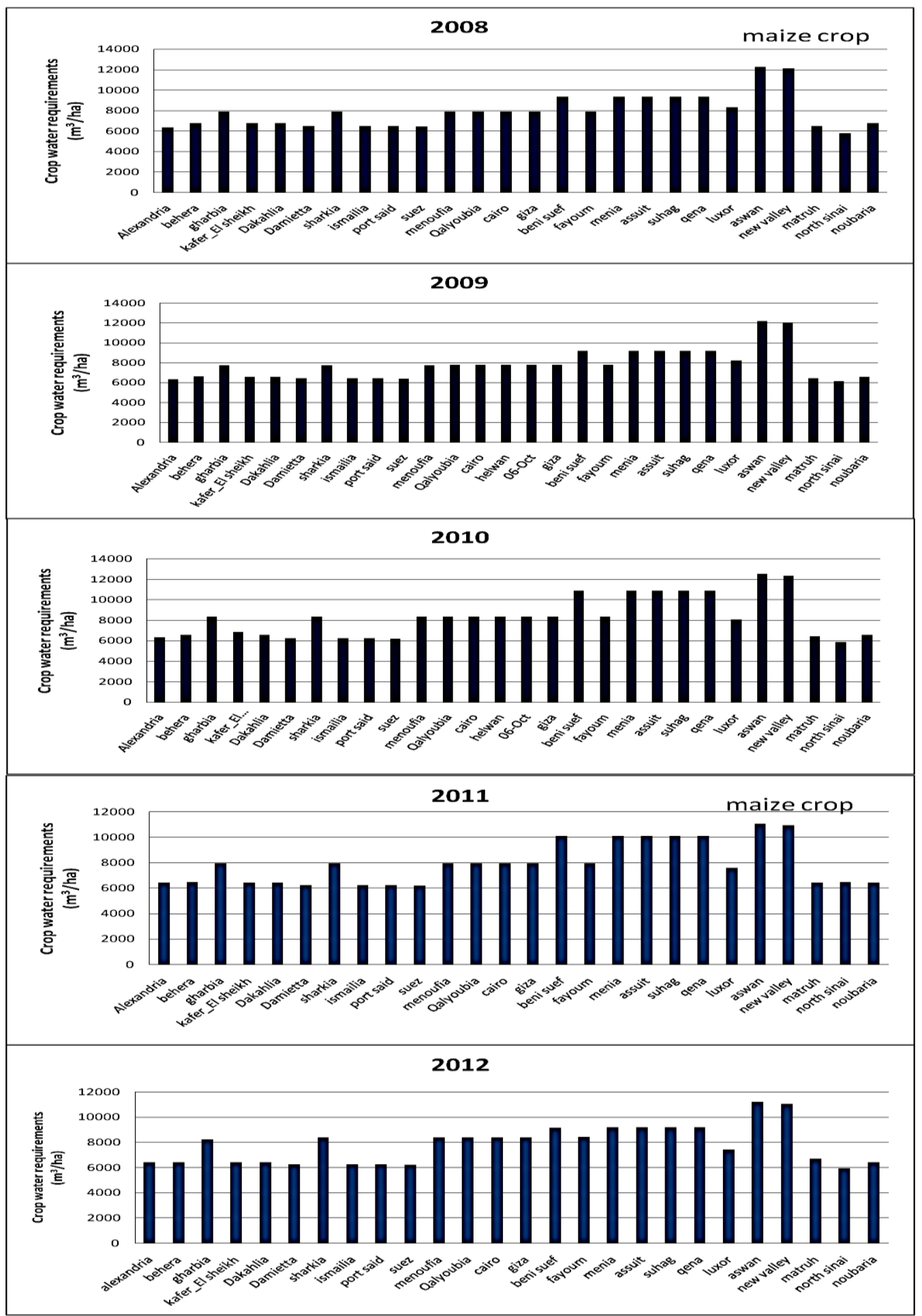

Figure 4: Crop water requirement for Maize in Egypt governorates from 2008 to 2012 
The previous results caused by the differences in soil type and climate conditions. While, the highest $\mathrm{WF}_{\text {grey }}$ was in North Sinai because it had the lowest Maize yield over this year. On the other hand, Dakahlia and Behera had the lowest $\mathrm{WF}_{\text {grey }}$ (533 and $569.5 \mathrm{~m}^{3} /$ ton).

\section{4- Total water footprint for Maize}

The water footprint analysis established the amount of water required by specific crops and it differs according to crop type, yield and climate. It dependant on the amount of nitrogen that applied to the soil. That is because $\mathrm{WF}_{\text {Tot }}$ had positive relationship with $\mathrm{WF}_{\text {grey }}$ while $\mathrm{WF}_{\text {grey }}$ has positive relationship with the amount of nitrogen that applied to the soil. As illustrated in Figure 6, North Sinai had the largest $\mathrm{WF}_{\text {Tot }}(6970.5$ $\mathrm{m}^{3} /$ ton, in average). Also, in New valley, Aswan and Qena governorates average $\mathrm{WF}_{\text {Tot }}$ over the study period were 3378.9, 3133.92 and 2966 $\mathrm{m}^{3} /$ ton, respectively. This result is due to lower Maize yield in this governorates. On the other hand, high Maize yield in Dakahlia and Noubaria decreases $\mathrm{WF}_{\text {Tot }}$ to 1227.4 and $1399.5 \mathrm{~m}^{3} /$ ton, respectively.

\section{Wheat crop}

\section{1- Cropping area}

Fayoum, Sharkia, Dakahlia, Behera governorates had the largest Wheat planted areas over years from 2008 to 2012 (Table 3). This is a general trend in Egypt, where Egypt government takes great efforts to increase wheat planted area to achieve self-sufficiency and stop import of Wheat.

\section{2- Crop water requirements for Wheat}

Figure 7 shows the CWR of Wheat for each governorate in Egypt over the period from 2008 to 2012. As illustrated from the average, CWR during the study period, South Sinai, Aswan, and New Valley had the largest CWR (10347.6, 10244.8 and $10149.2 \mathrm{~m}^{3} / \mathrm{ha}$, respectively). On the other hand, due to climatic conditions, Ismailia, Port Said, Suez and Matruh had the lowest CWR (5350.8, 5350.2, 5332.6 and $5578.4 \mathrm{~m}^{3} /$ ha, respectively).

\section{3- Green, blue, and grey water footprint for Wheat}

Figure 8 shows that, the average lowest $\mathrm{WF}_{\text {blue }}$ over the period from 2008 to 2012 for Wheat was in Damietta, Behera, Kafer El-shiekh and Suez (811.8, 832.2, 837.2 and $845.2 \mathrm{~m}^{3} /$ ton, respectively). In 2009, Kafer Elshiekh had the lowest $\mathrm{WF}_{\text {blue }}$ for Wheat $\left(799.6 \mathrm{~m}^{3} /\right.$ ton). 


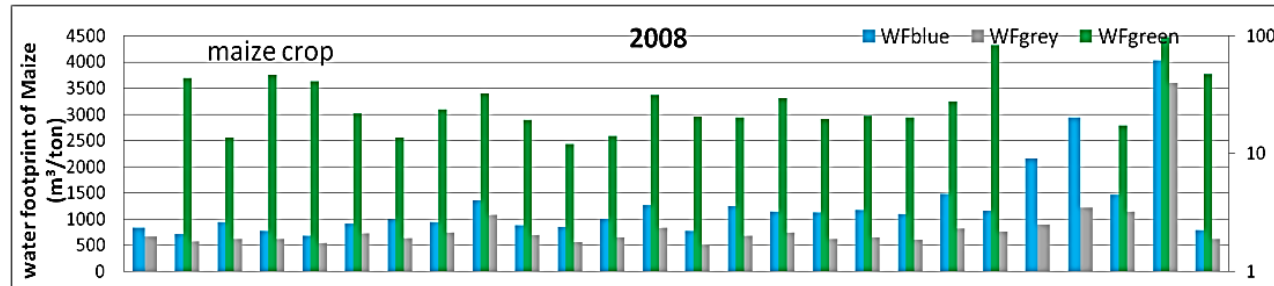

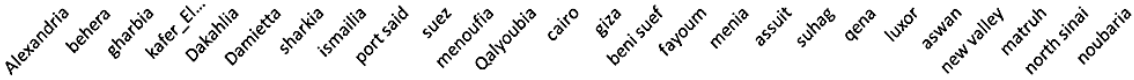
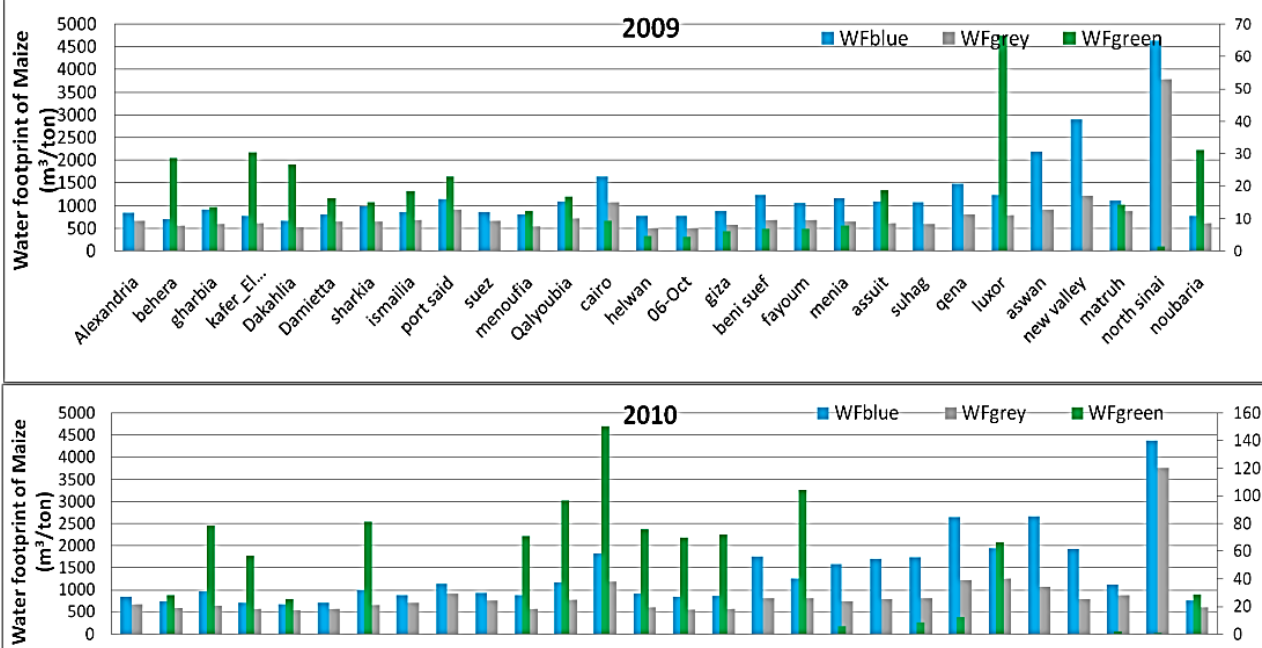

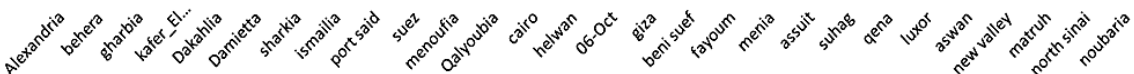

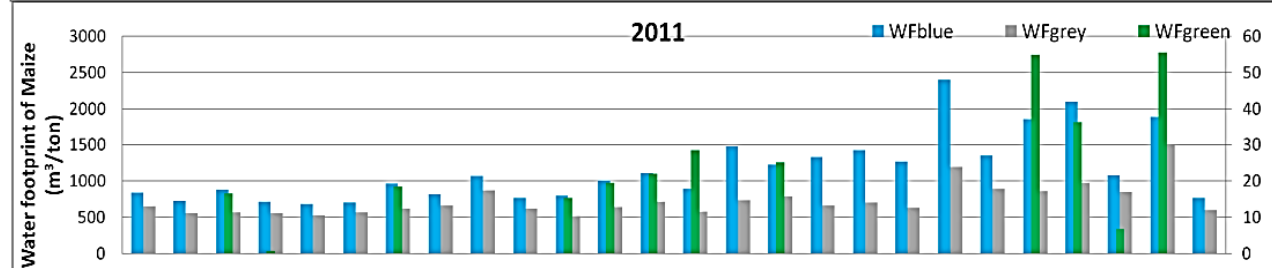

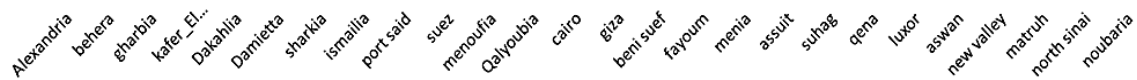

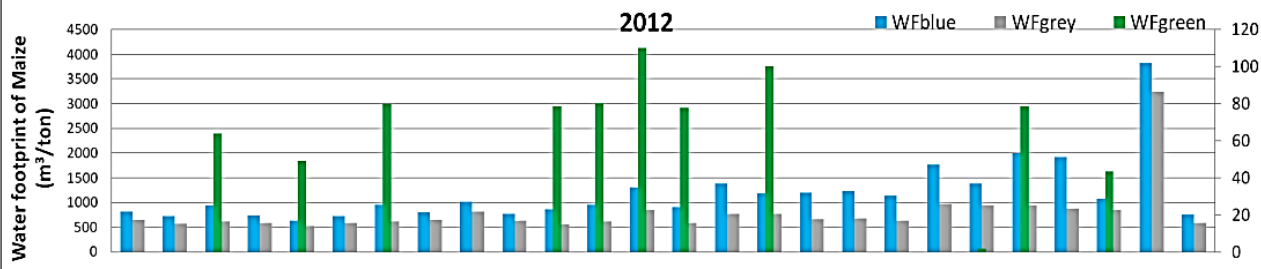

$0^{20^{20}}$

Figure 5: Green, blue and grey water footprint for Maize in Egypt governorates from 2008 to 2012. 


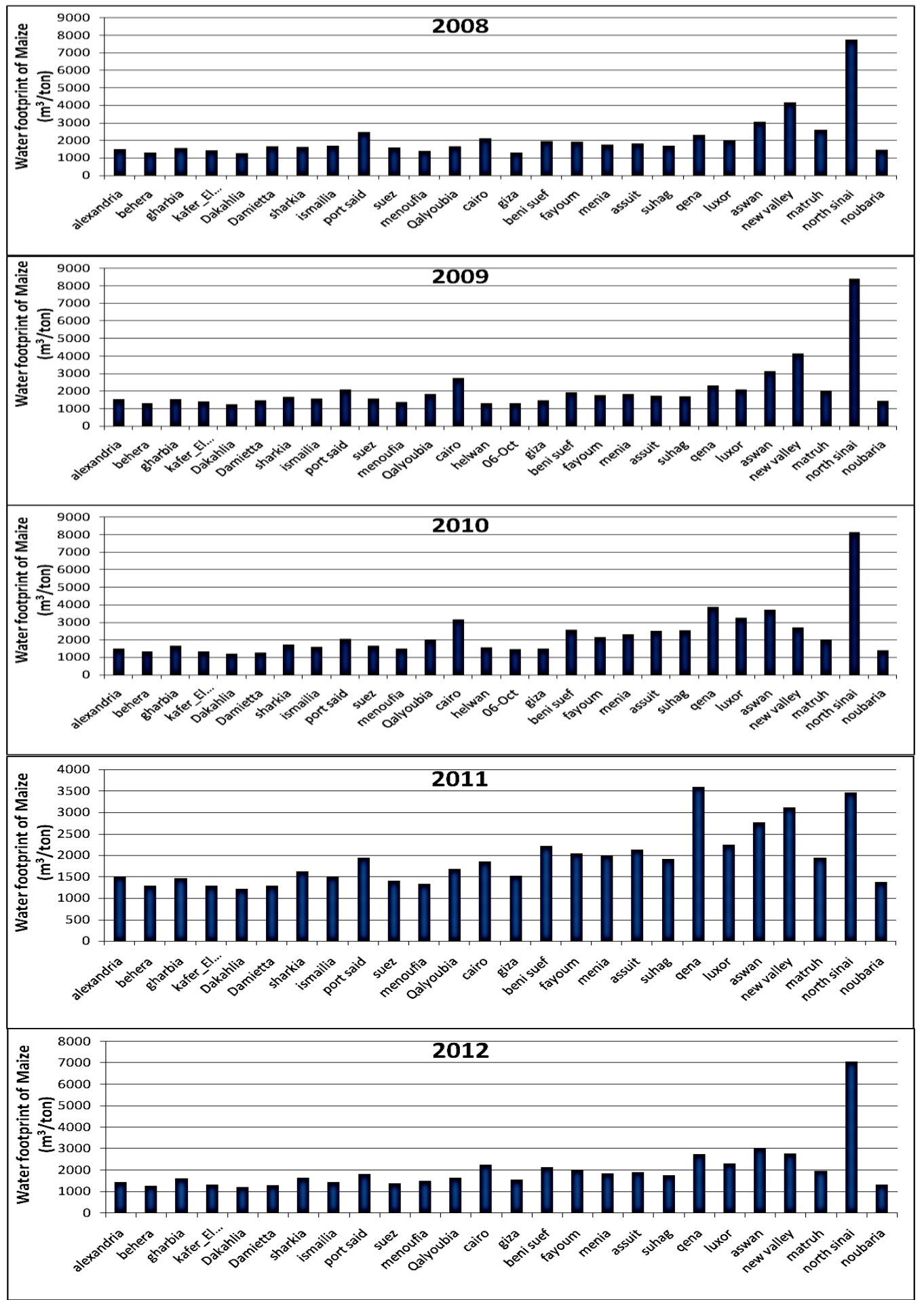

Figure 6: Total water footprint for Maize in Egypt governorates from 2008 to 2012. 
On the other hand, South Sinai had the highest $\mathrm{WF}_{\text {blue }}$ for Wheat from year 2008 to 2012. These results caused by the differences in soil type and climate conditions in these governorates. As well as, the highest $\mathrm{WF}_{\text {grey }}$ was in South Sinai $\left(934.9 \mathrm{~m}^{3} / \mathrm{ton}\right)$ because it had the lowest Wheat yield. In 2008, 2009, 2011, and 2012. Menoufia had the lowest $W_{\text {grey }}$ due to the highest Wheat yield. While, the $\left(\mathrm{WF}_{\text {green }}\right.$ was depended on rain in each governorate.

Table 3: The planted Maize area (ha) for Egypt governorates from 2008 to 2012

\begin{tabular}{|l|c|c|c|c|c|c|}
\hline \multirow{2}{*}{ Governorates } & \multicolumn{7}{|c|}{ Area (ha) } \\
\cline { 2 - 7 } & 2008 & 2009 & 2010 & 2011 & 2012 & Average \\
\hline Alexandria & 27186 & 28349 & 25378 & 26440 & 32884 & 28047.4 \\
\hline Behera & 115142 & 139476 & 123168 & 133372 & 135037 & 129239 \\
\hline Gharbia & 65685 & 68892 & 62110 & 61538 & 63432 & 64331.4 \\
\hline kafer_El-sheikh & 98151 & 109961 & 98621 & 100630 & 99236 & 101319.8 \\
\hline Dakahlia & 121927 & 129010 & 124482 & 126008 & 127380 & 125761.4 \\
\hline Damietta & 12598 & 11184 & 11588 & 13434 & 12433 & 12247.4 \\
\hline Sharkia & 146580 & 175731 & 167964 & 169669 & 178513 & 167691.4 \\
\hline Ismailia & 17360 & 19641 & 22738 & 21008 & 22595 & 20668.4 \\
\hline Port said & 6575 & 8213 & 7955 & 8410 & 7016 & 7633.8 \\
\hline Suez & 1657 & 1829 & 2051 & 1871 & 1959 & 1873.4 \\
\hline Menoufia & 45939 & 51876 & 45171 & 46560 & 53168 & 48542.8 \\
\hline Qalyoubia & 21921 & 21135 & 20624 & 20839 & 22293 & 21362.4 \\
\hline Cairo & 85 & 41 & 11 & 11 & 34 & 36.4 \\
\hline Giza & 15929 & 187 & 168 & 90 & 17026 & 6680 \\
\hline beni Suef & 57139 & 58583 & 53642 & 54859 & 52971 & 55438.8 \\
\hline Fayoum & 63694 & 66837 & 70677 & 687362 & 73426 & 192399.2 \\
\hline Menia & 88184 & 97024 & 89194 & 89786 & 91834 & 91204.4 \\
\hline Assuit & 71777 & 70976 & 69016 & 69869 & 80176 & 72362.8 \\
\hline Suhag & 72518 & 74807 & 75846 & 78120 & 73516 & 74961.4 \\
\hline Qena & 49981 & 58562 & 40587 & 39588 & 44570 & 46657.6 \\
\hline Luxor & 7144 & 6962 & 14662 & 15535 & 16951 & 12250.8 \\
\hline Aswan & 11848 & 16349 & 19501 & 18906 & 21946 & 17710 \\
\hline New Valley & 20760 & 24036 & 27508 & 35418 & 43397 & 30223.8 \\
\hline Matruh & 22167 & 12684 & 10321 & 3654 & 1886 & 10142.4 \\
\hline North Sinai & 883 & 0 & 0 & 0 & 105 & 494 \\
\hline South Sinai & 13 & 10 & 54 & 23 & 89 & 37.8 \\
\hline Noubaria & 63693 & 54266 & 56957 & 58967 & 53579 & 57492.4 \\
\hline
\end{tabular}




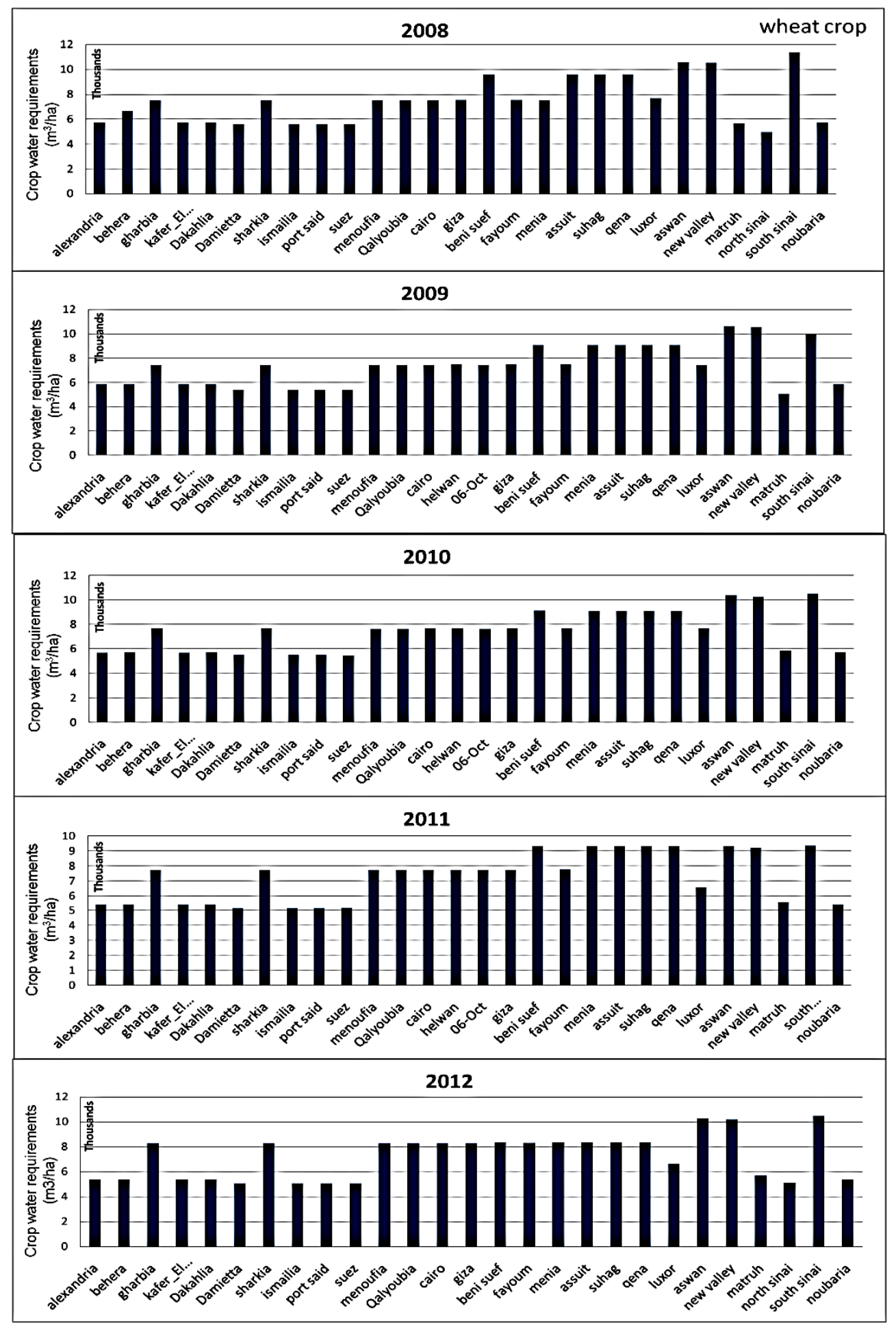

Figure 7: Crop water requirements for Wheat in Egypt governorates from 2008 to 2012 


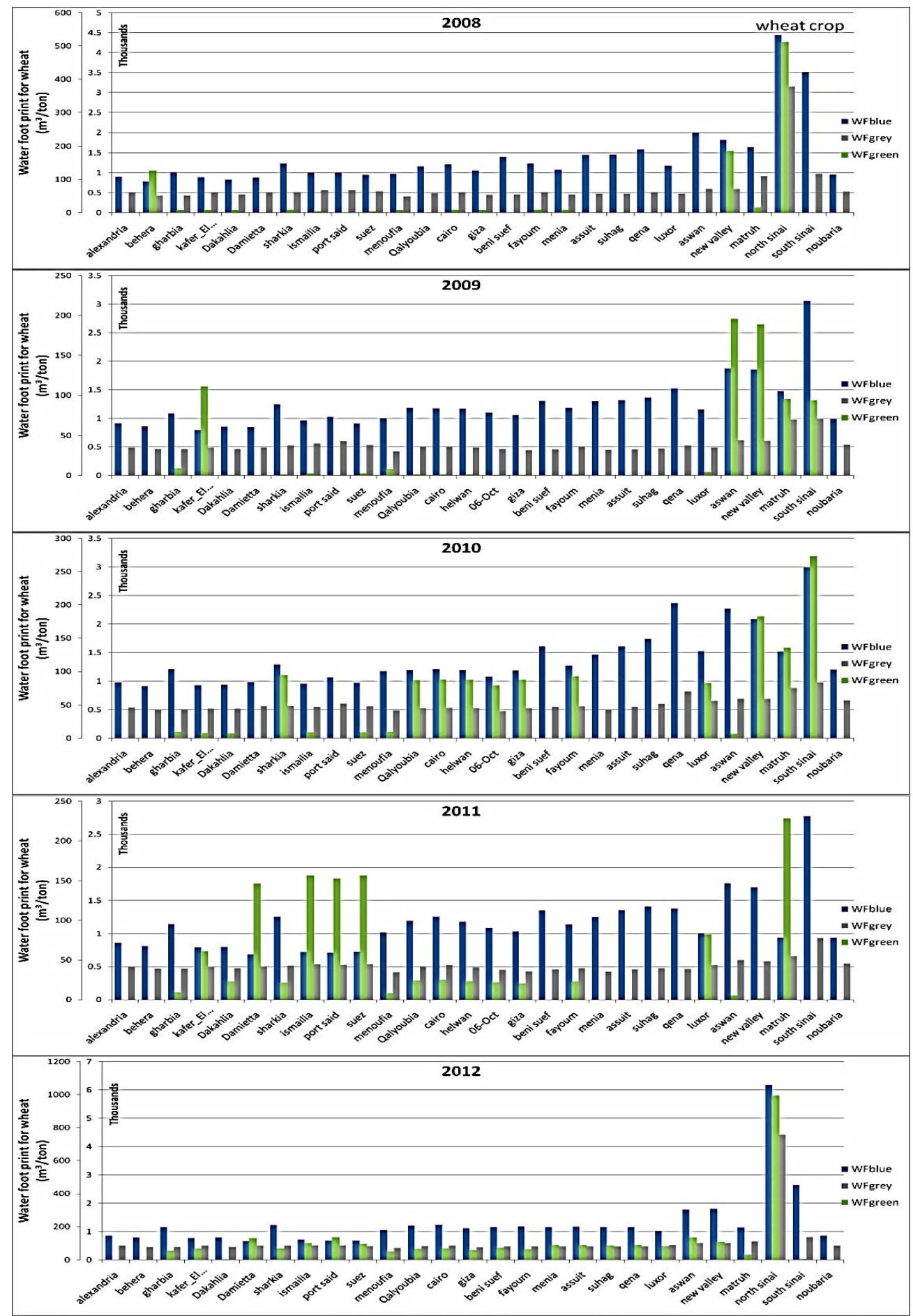

Figure 8: The green, blue and grey water footprint of Wheat in Egypt governorates from 2008 to 2012. 


\section{4- Total water footprint for Wheat}

For each governorate, the average of the studied years was estimated for $\mathrm{WF}_{\text {Tot }}$. Figure 9 shows The total water footprint for Wheat in governorates over the period from 2008 through 2012. South Sinai governorate had the lowest Wheat yield therefore, the highest $\mathrm{WF}_{\mathrm{Tot}}$ was in it. Followed by New Valley, Aswan and Matruh (2604.1, 2620.4 and $2261 \mathrm{~m}^{3} /$ ton, respectively). On the other hand, Behera, Dakahlia, Damietta and Kafer El-shiekh governorates had the lowest $\mathrm{WF}_{\text {Tot }}$ (1323.1, 1323.3, 1378.1 and $1387.1 \mathrm{~m}^{3} /$ ton, respectively) in consequence of high Wheat yield.

\section{CONCLUSIONS}

Irrigation water requirements and Water footprint for Rice, Maize and Wheat in Egypt governorates over the period from year 2008 to 2012 was estimated in this study. The results for each crop were as follows:

\section{Rice Crop:}

New Valley had the largest average of CWR $\left(15840.2 \mathrm{~m}^{3} / \mathrm{ha}\right)$. On the contrary, the lowest CWR were in Ismailia and Port Said (8608.8, 8608.4 $\mathrm{m}^{3} /$ ha, respectively). As a reason of differences among governorates climatic conditions. Dakahlia had the lowest $\mathrm{WF}_{\text {blue }}$ for Rice (848.7 $\mathrm{m}^{3} /$ ton $)$. Also it had the lowest $\mathrm{WF}_{\text {grey }}\left(242.3 \mathrm{~m}^{3} /\right.$ ton $)$ due to the highest Rice yield. On the other hand, the highest $\mathrm{WF}_{\text {blue }}$ for Rice in 2008 to 2012 was in New Valley $\left(1977.2 \mathrm{~m}^{3} /\right.$ ton $)$ and its average $W_{\text {grey }}$ is $314.5 \mathrm{~m}^{3} / \mathrm{ha}$. The $\mathrm{WF}_{\text {green }}$ has less effect than the others due to the rare rainfall in Egypt in general.

Water footprint differs according to crop and soil type, yield and climate. Water footprint also depends on the amount of nitrogen applied to the soil during growing season. New Vally and Noubaria had the largest $\mathrm{WF}_{\text {Tot }}\left(2292\right.$ and $2200 \mathrm{~m}^{3} /$ ton $)$. As a reason of the hot climate and lower Rice yield in governorates. On the other hand, Dakahlia had the lowest $\mathrm{WF}_{\text {Tot }}\left(1101.8 \mathrm{~m}^{3} /\right.$ ton $)$. Followed by Kafr El-Sheikh and Damietta had low values (1214.9 and $1280.3 \mathrm{~m}^{3} /$ ton, respectively).

\section{Maize Crop}

New Valley and Aswan had the largest CWR for Maize (11707.8 and $11860.4 \mathrm{~m}^{3} / \mathrm{ha}$, respectively) while, North Sinai had the lowest values $\left(606.6 \mathrm{~m}^{3} / \mathrm{ha}\right)$. As a reason of differences among governorates climatic conditions. 


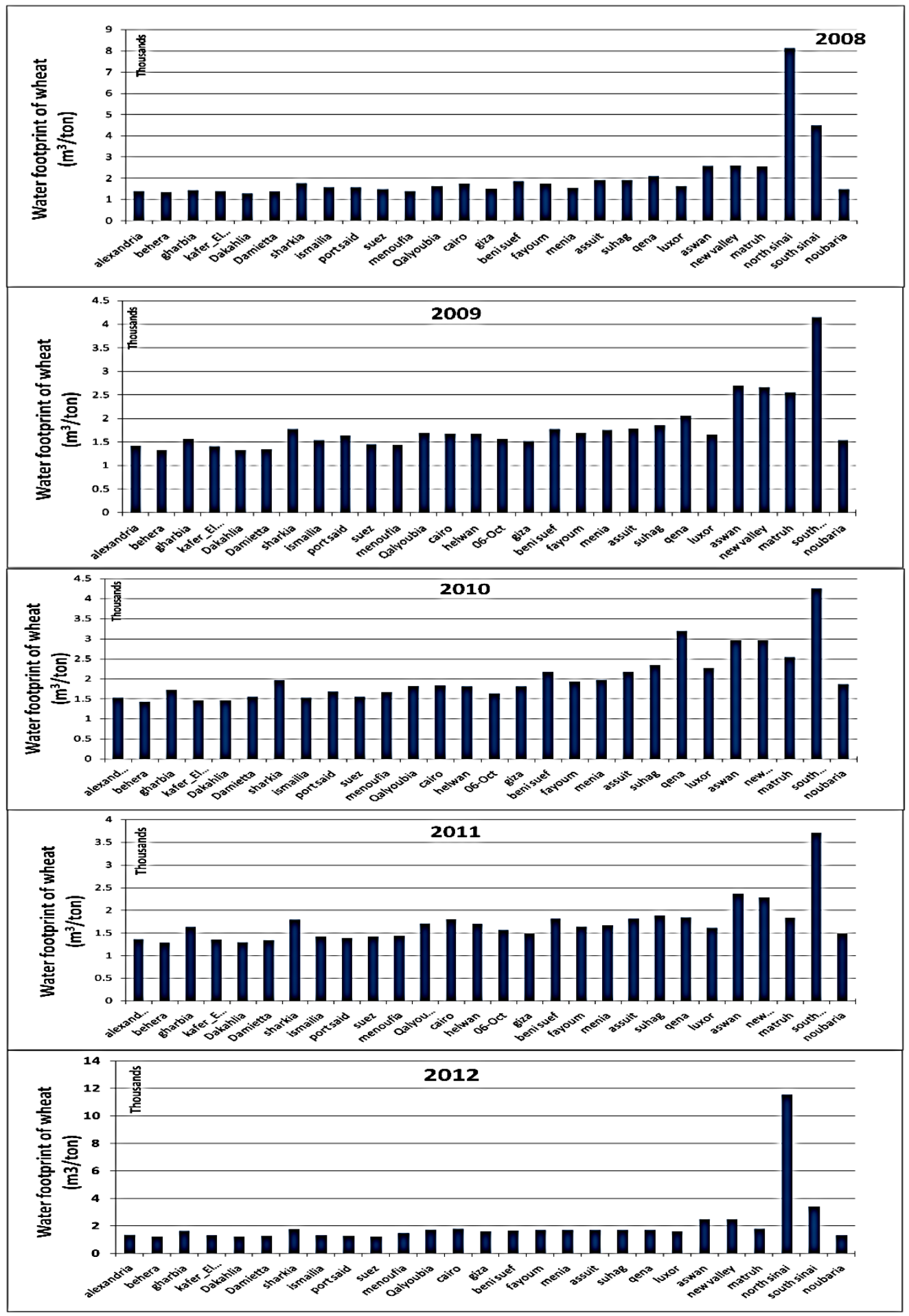

Figure 9: The total water footprint for Wheat in Egypt governorates from 2008 to 2012 
The average $\mathrm{WF}_{\text {blue }}$ through the study period for Dakahlia, Noubaria and Damietta were $665.8,770.2$ and $774.2 \mathrm{~m}^{3} /$ ton, respectively. On the contrary, the highest $\mathrm{WF}_{\text {blue }}$ for Maize for the study period was in North Sinai, New Valley and Aswan (376, 2355.4 and $2173.2 \mathrm{~m}^{3} /$ ton, respectively). The previous results caused by the differences in soil type and climate conditions. While, the highest $\mathrm{WF}_{\text {grey }}$ was in North Sinai because it had the lowest Maize yield. On the other hand, Dakahlia and Behera had the lowest $\mathrm{WF}_{\text {grey }}$ (533 and $569.5 \mathrm{~m} \mathrm{~m}^{3} /$ ton).

North Sinai had the largest $\mathrm{WF}_{\text {Tot }}\left(6970.5 \mathrm{~m}^{3} /\right.$ ton in average). Also in New valley, Aswan and Qena governorates average total water footprint over the study period were $3378.9,3133.92$ and $2966 \mathrm{~m}^{3} /$ ton, respectively. This result was due to lower Maize yield in this governorates. On the other hand, high Maize yield in Dakahlia and Noubaria decreases $\mathrm{WF}_{\mathrm{Tot}}$ to 1227.4 and $1399.5 \mathrm{~m}^{3} /$ ton, respectively.

\section{Wheat Crop}

During the study period, South Sinai, Aswan, and New Valley had the largest CWR (10347.6, 10244.8 and $10149.2 \mathrm{~m}^{3} / \mathrm{ha}$, respectively). On the other hand, due to climatic conditions, Ismailia, Port Said, Suez and Matruh had the lowest crop water requirements (5350.8, 5350.2, 5332.6 and $5578.4 \mathrm{~m}^{3} / \mathrm{ha}$, respectively).

The average lowest $\mathrm{WF}_{\text {blue }}$ over the period from 2008 to 2012 for Wheat was in Damietta, Behera, Kafer El-shiekh and Suez (811.8, 832.2, 837.2 and $845.2 \mathrm{~m}^{3} /$ ton, respectively). As well as, the highest $\mathrm{WF}_{\text {grey }}$ was in South Sinai $\left(934.9 \mathrm{~m}^{3} / \mathrm{ton}\right)$ because it had the lowest Wheat yield.

South Sinai governorate had the lowest Wheat yield therefore, the highest $\mathrm{WF}_{\mathrm{Tot}}$ was in it. Followed by New Valley, Aswan and Matruh (2604.1, 2620.4 and $2261 \mathrm{~m}^{3} /$ ton, respectively). On the contrary, Behera, Dakahlia, Damietta and Kafer El-shiekh governorates had the lowest $\mathrm{WF}_{\text {Tot }}$ (1323.1, $1323.3,1378.1$ and $1387.1 \mathrm{~m}^{3} /$ ton, respectively). As a reason of high yield.

Finally; according the previous results of $\mathrm{CWR}$ and $\mathrm{WF}_{\mathrm{Tot}}$ for different governorates in Egypt, the suggested strategy for growing crops in Egypt could explained as follows: 
- Increase the Rice cultivation area in Dakahlia, Kafr El-Sheikh and Damietta. Also, make efforts to decrease it in other governorates such as Noubaria and New Vally

- Increase Maize cultivation area in Dakahlia and Noubaria. On the other hand, decrease the planting Maize area in some governorates such as North Sinai, New valley, Aswan and Qena.

- Increase Wheat cultivation areas in Behera, Dakahlia, Damietta and Kafer El-sheikh and decrease it in South Sinai, New Valley, Aswan and Matruh governorates.

\section{REFERENCES}

Aldaya. M.M and M.R. Llamas, (2008). Water footprint analysis for the Guadiana river basin. Available at: http://www. waterfootprint.org/ Reports/Report35.pdf. Accessed on 10 Feb 2013. Value of water research report series No (35), pp 1-8.

Allen, R. G.; L. S. Pereira; D. Raes; and M. Smith. (1998). Crop evapotranspiration: Guidelines for computing crop water requirements. FAO Irrigation and Drainage Paper 56. Food and Agriculture Organization. Rome.

Bulsink, F., A. Hoekstra, M.J. Booij, (2010). The water footprint of Indonesian provinces related to the consumption of crop products. Hydrol. Earth Syst. Sci. (14), PP 119-128.

Chapagain, A. K. and A. Y. Hoekstra. (2004). Water footprints of nations. Available at: www. waterfootprint.org /Reports/ Report 16 Vol1.pdf. Accessed on 30 Feb 2013, Value of Water Research Report Series No (16), Pages 80, UNESCO-IHE, and Delft, Netherlands.

Chapagain, A.K. and A.Y. Hoekstra. (2003). Virtual water trade: A quantification of virtual water flows between nations in relation to international trade of livestock and livestock products. In: Hoekstra (ED) .Virtual water trade: Proceedings of the International Expert Meeting on Virtual Water Trade. Value of Water Research Report Series No. (12), pages 248, UNESCO-IHE Institute for Water Education, Delft, the Netherlands. 
FAO (2003). Technical Conversion Factors for Agricultural Commodities. Available at:

http://www.fao.org/fileadmin/templates/ess/documents

/methodology/tcf.pdf. Accessed on: 30 Sep 2014.page 1:728.

Felix, G. (2012). The Swiss Water Footprint Report: A global picture of Swiss water dependence. Pages 36. Available at: http://www.WWF-SDC-2012 Swiss water footprint.pdf. Accessed on $23 \mathrm{Feb} 2013$.

Gerbens-Leenes P. W.; and A.Y. Hoekstra. (2008). Business water footprint accounting: A tool to assess how production of goods and services impacts. Available at: http://www.waterfootprin t.org/Reports/Report27 .Accessed on 21 Sep 2014.

Hoekstra, A.Y., A.K. Chapagain, M.M. Aldaya, and M.M. Mekonnen. (2011). The water footprint assessment manual. Available at:http://www.waterfootprint.org/downloads/ Accessed on 25 Jan.2013. Water Footprint Network 2011.Pages 228.

Hoekstra, A. Y. and P. Q. Hung. (2005). Globalisation of water resources: international virtual water flows in relation to crop trade, Global Environmental Change 15(1), PP 45-56.

Hoekstra, A.Y. and P.Q. Hung. (2002). A quantification of virtual water flows between nations in relation to international crop trade. Value of Water Research Report Series No (11), PP 1-120, UNESCO-IHE Institute for Water Education, Delft, the Netherlands.

Liu, J. and H.H.G. Savenije, (2008). Food consumption patterns and their effect on water requirement in China. Hydrol. Earth Syst. Sci. (12), PP 887-898.

Mekonnen, M.M. (2011). Spatially and temporally explicit water footprint accounting. Available at: http://doc.utwente.nl/78027/1/thesis__ MM_Mekonnen.pdf. Accessed 3. Feb.2013. 
USDA (United States Department of Agriculture) and MSU Extension Service Staff. (1990). Irrigation Water Management When and How Much to Irrigate. Pages: 6. (Soil \& Water) MT8901 AG Available at: http://animalrangeextension.montana.edu/articles/forage/crop_irri gation.pdf Accessed 13. Sep .2013.

Van Oel, P., M. Mekonnen, and A. Hoekstra, (2009). The external water footprint of the Netherlands: geographically-explicit quantification and impact assessment. Ecol. Econ. (69), PP 82-92.

Verma, S., D.A. Kampman, P. van der Zaag, A.Y. Hoekstra, (2009). Going against the flow: a critical analysis of inter-state virtual water trade in the context of India's National River Linking Program. Physical Chemical Earth 34, PP 261-269

\section{الملخص العربي}

استراتيجية توزيع بعض المحاصيل في محافظات مصر باستخدام البصمة المائية

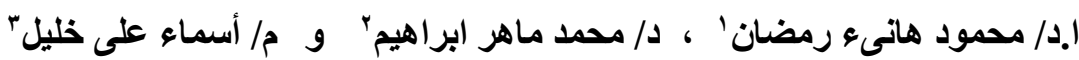

تعانى مصر عجز كبير فى المياه نتيجة للزيادة السكانية المضطردة ومحدودية مياة الري بالإضافة

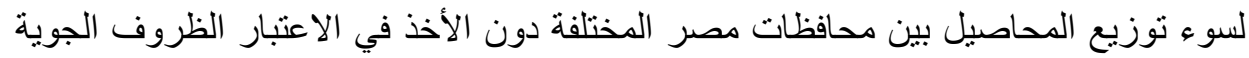

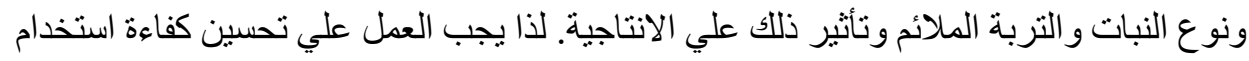

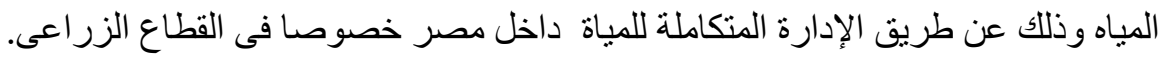

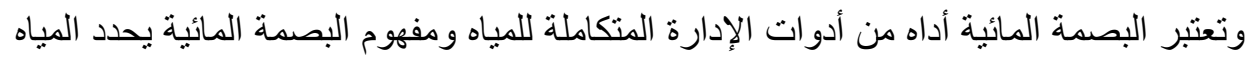

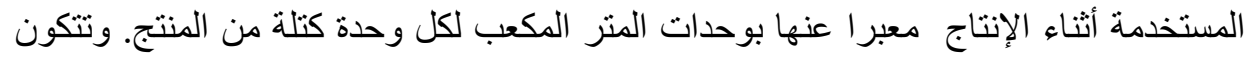

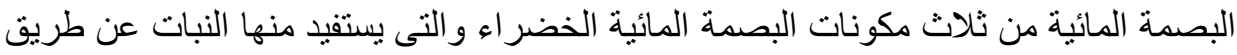

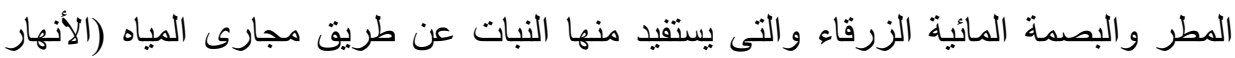

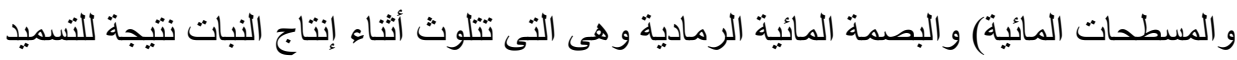
النيتروجينى طو ال فترة نمو النبات.

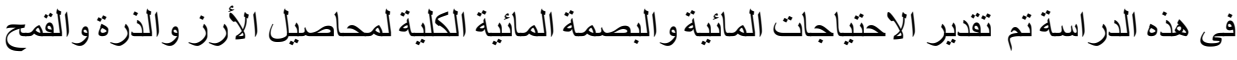

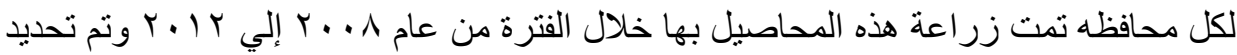

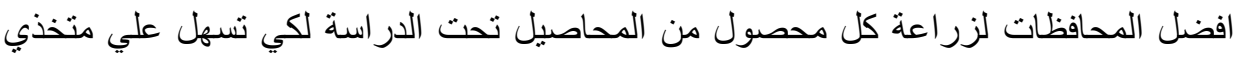
القرار عملية توزيع المحاصيل علي المحافظات المختلفة ـ وكانت النتائج كالأتى:

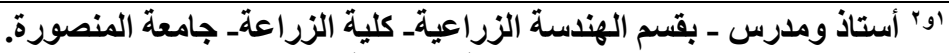
"اخصائى زراعى- بمعهد بحوث الهندسة الزراعيةـ بالدقىـ القاهرة. 
بالنسبة لمحصول الأرز فإن أفضل محافظة لزر اعته داخل مصر هى محافظات الدقهلية وكفر

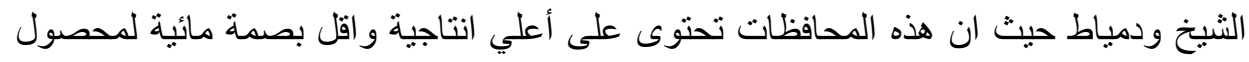

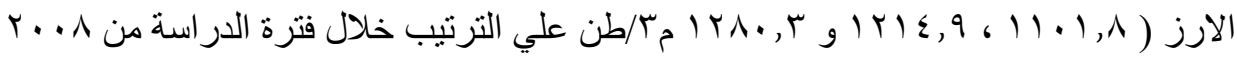

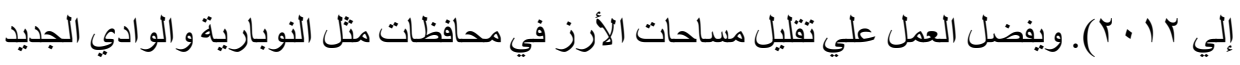

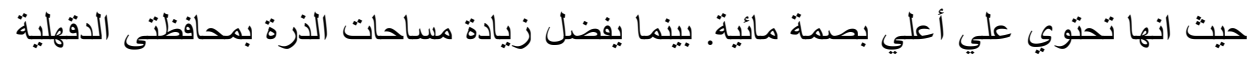

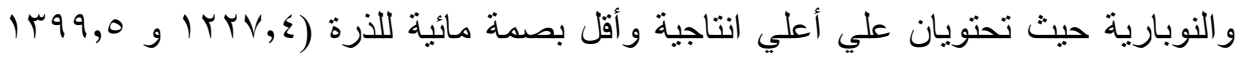

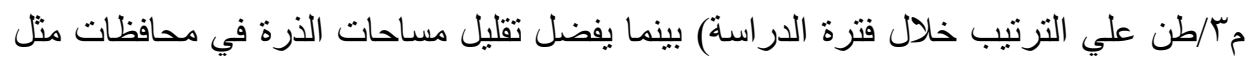

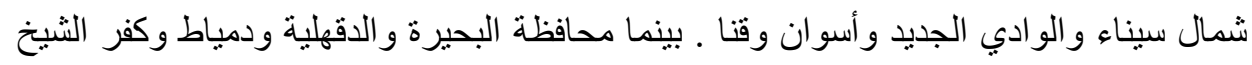

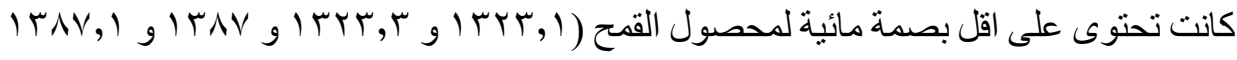

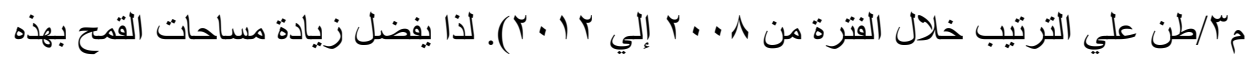

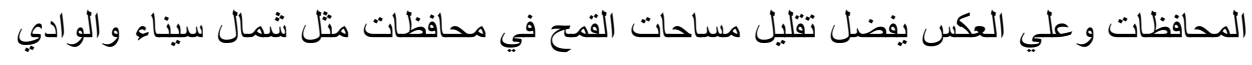

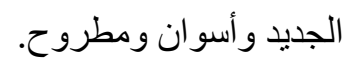

